\title{
Perception of MBBS students towards online education during the COVID-19 pandemic period.
}

1. MBBS, DLO, FCPS Associate Professor ENT Shaheed Mohtarma Benazir Bhutto Medical University.

2. MBBS, MHP

Lecturer Medical Education MC Mirpur AJK

3. MBBS, FCPS Assistant Professor ENT DHQ-TH, Mirpur AJK

4. MBBS, DLO, FCPS ENT Specialist DHQ-TH Mirpur AJK.

5. MBBS, M.Phil

Professor Pathology MBBSMC Mirpur AJK.

6. MBBS, M.Phil

Assistant Professor Pathology MBBSMC Mirpur AJK.

Correspondence Address:

Dr. Faisal Bashir

Department of ENT

Shaheed Mohtarma Benazir Bhutto

Medical University.

khawajaent2520@gmail.com

Article received on:

23/09/2020

Accepted for publication:

$20 / 11 / 2020$

\section{INTRODUCTION}

This study is related to the efficiency of online education from the perspective of students. Study included a survey about the performance of instructor, environment and management of online classes and examination pattern. This survey was conducted on $4^{\text {th }}$ year MBBS student of otorhinolaryngology enrolled in Mohtarma Benazeer Bhutto Shaheed Medical College (MBBSMC), Mirpur, Azad Jammu Kashmir (AJK). The COVID-19 outbreak emerged as a global public health emergency in early $2020 .{ }^{1}$ In Pakistan, the COVID-19 emergence started in late February as the first case of COVID-19 was confirmed by the Health Ministry of Pakistan. ${ }^{2}$ As of 20th September 2020, the total numbers of infected cases of COVID-19 in the country are standing at figure 305,671 with 6,416 deaths. $^{3}$ Out of the fear of outbreak in the educational CoV-2
Faisal Bashir ${ }^{1}$, Amna Ahmad Noor ${ }^{2}$, Ejaz Ahmad ${ }^{3}$, Zafryab Ali ${ }^{4}$, Syed Manzoor Iqbal ${ }^{5}$, M. Kaleem ${ }^{6}$

ATRACT...Objective: This research study evaluated the perception of students of of instructors during online lectures. Study Design: Cross Sectional study. Setting: Medica Education Department Shaheed Mohtarma Benazir Bhutto Medical University. Period: 19 May August 2020. Material \& Methods: The information collected through feedback form course and examination. The responses to questions included options of strongly agree, agree, uncertain, disagree and strongly disagree. Results: The findings of the study revealed that (t) performances of instructors during COVID-19 resulting on person interaction with the instructor, lack of traditional lecture hall environment etc., students of Key words: $\quad$ Medical Education, Online Education, Pandemics, Survey Methods, SARSMBBS students of Mohtarma Benazeer Bhutto Shaheed Medical College, period. Professional Med J 2021; 28(3):392-398. https://doi.org/10.29309/TPMJ/2021.28.03.6101

institutions, Government of Pakistan turned their attention towards shut down of the all educational institutions across the nation in early March. Sequentially, the Higher Education Commission (HEC) set the parameters for higher education institutions of the country to adapt online or distance learning and examination models until the COVID19 crisis sustains. ${ }^{4}$ Many observers predicted at that time that COVID-19 resulting situation will impact theacademicsectormassively, including having effects on students, teachers, and educational activities all around the globe. ${ }^{5}$ To make the online learning model successful, educational institutions premises were closed for entry so that students could follow the mandatory social distancing measures while still carrying out their educational activities online. ${ }^{6}$ Globally, while the online education model was adapted quickly at the administration levels, the smooth transition 
from an environment of conventional lecture hall to a computer screen could not happen easily because of various issues. ${ }^{7}$ It must be mentioned here that for online education including both teaching or delivering of lectures and examinations to be effective, an overall national level advanced digital environment is required. ${ }^{8}$ However, in Pakistan, limited access to fast and reliable internet hinders this process of effective online education, specifically for students from rural areas and underdeveloped communities of the nation. ${ }^{9}$ This study evaluates the effectiveness of the newly adapted online education model in Pakistan from the eyes of students.

Literature survey has revealed that in recent times many education institutes all across the globe are adapting online education and more and more students are leaning towards this model of learning. ${ }^{10,11}$ At the same time, research has also been published highlighting the limitations of online education such as lack of social educational environment, lack of interaction between students and instructor and also issues related to connectivity etc. ${ }^{12,13}$ So far published research literature on online education during COVID-19 has described same limitations related to schedules, use of resources and tools, student's assessment, effectiveness of communication, the lack of in-person interaction between student and the instructor. ${ }^{14,15}$ Some authors have explored the advantages of online education along with the issues faced, from the perspective of various stakeholders, ${ }^{5}$ such as students, instructors etc. Some authors have highlighted the factors behind variation in quality of online education. Basilaia and Kvavadze ${ }^{7}$ suggested that the quality of learning online should be investigated in future research studies because effectiveness can vary from student to student based upon their location within the country and available resources. Before COVID-19, studies conducted on medical students of Pakistani universities showed that the students were satisfied with the online learning system of their respective universities. ${ }^{16}$ One study conducted among the students of Khyber Pakhtunkhwa (KPK) province concluded that majority of the higher education students had access of technology and online skills. ${ }^{9}$
This study is to identify challenges to the online education environment which may delay the adoption of online education from the perspective of the students. To make such model effective, opinions of the stakeholders such as students need to be brought to the light first. ${ }^{17,18}$ Prior to COVID-19, although most of the research on online education in Pakistan has been conducted in a normal or healthy circumstance, ${ }^{19}$ where e-learning is just one optional mode of higher education offered by very few national academic institutions like Allama lqbal Open University (AIOU), Bahauddin Zakaria University (BZU) and Virtual University (VU) of Pakistan to name few. These researches have revealed that some very promising benefits of online or distance learning. This was supplemented by the facts such as distance learning content in the host institutions is well-designed and kept modern and updated and also, the instructors in these institutions are quite well trained with the required skills and possess the required information to be delivered to the student. But COVID-19 resultant online education is different from the normal circumstances distance learning programs because all higher education institutions across the country are forced to adapt the mandatory distance learning model despite majority of them having limited resources for such activity. Many had no prior experience to conduct such education before either. Thus, a lot more research work in form of surveys is required to explore the issues of online education that hinders students from achieving their optimal learning goals. Hence, this study revolves around the opinions of students regarding effective of online education in their institutions. For the evaluation of the online classes in otorhinolaryngology for MBBS students, we divided survey into main three parts. (1) To know the actual impact or effectiveness of instructor's performance during online education from the perspective of higher education students $^{3}$ (2) To determine the effectiveness of online education in terms of maintenance of the effective learning environment of online classes (3) To determine the impact of online model on effectiveness of assignments and examinations. 


\section{MATERIAL \& METHODS}

The cross-sectional survey was conducted to find the general attitudes of the $4^{\text {th }}$ year medical students of MBBSMC towards mandatory online education during Coronavirus (COVID-19). The sampling technique was purposive sampling technique with the sample size of 73 participants including male and female participants. Fourth year MBBS Students of age 21-24 years were included in this study who attended online classes.

Feedback forms filled by total 73 total students without identification were submitted to medical education department and earn nose throat (ENT) department for evaluation. Survey activity

\begin{tabular}{|c|c|c|c|c|c|}
\hline Questions & $\begin{array}{c}\text { Strongly } \\
\text { agree } \\
\text { n(\%) }\end{array}$ & $\begin{array}{c}\text { Agree } \\
\mathrm{n}(\%)\end{array}$ & $\begin{array}{l}\text { Uncertain } \\
\text { n (\%) }\end{array}$ & $\begin{array}{l}\text { Disagree } \\
\text { n (\%) }\end{array}$ & $\begin{array}{c}\text { Strongly } \\
\text { disagree } \\
\text { n (\%) }\end{array}$ \\
\hline The Instructor is prepared for each class: & $57(78.1)$ & 16 (21.9) & $0(0)$ & $0(0)$ & $0(0)$ \\
\hline The Instructor demonstrates knowledge of the subject & $58(79.5)$ & $14(19.2)$ & $1(1.4)$ & $0(0)$ & $0(0)$ \\
\hline The Instructor has completed the whole course & $29(39.7)$ & $27(37.0)$ & $17(23.3)$ & $0(0)$ & $0(0)$ \\
\hline $\begin{array}{l}\text { The Instructor provides additional material apart from the } \\
\text { textbook }\end{array}$ & $49(67.1)$ & $22(30.1)$ & $2(2.7)$ & $0(0)$ & $0(0)$ \\
\hline $\begin{array}{l}\text { The Instructor gives citations regarding current situations } \\
\text { with reference to Pakistani context. }\end{array}$ & $38(52.1)$ & $27(37.0)$ & $8(11.0)$ & $0(0)$ & $0(0)$ \\
\hline The Instructor communicates the subject matter effectively & $54(74.0)$ & $19(26.0)$ & $0(0)$ & $0(0)$ & $0(0)$ \\
\hline $\begin{array}{l}\text { The Instructor shows respect towards students and } \\
\text { encourages class participation }\end{array}$ & $55(75.3)$ & $18(24.7)$ & $0(0)$ & $0(0)$ & $0(0)$ \\
\hline $\begin{array}{l}\text { The Instructor maintains an environment that is conducive } \\
\text { to learning }\end{array}$ & $56(76.7)$ & $17(23.3)$ & $0(0)$ & $0(0)$ & $0(0)$ \\
\hline The Instructor arrives on time & $56(76.7)$ & $16(21.9)$ & $1(1.4)$ & $0(0)$ & $0(0)$ \\
\hline The Instructor leaves on time & $52(71.2)$ & $20(27.4)$ & $1(1.4)$ & $0(0)$ & $0(0)$ \\
\hline The Instructor is fair in examination & $54(74.0)$ & $18(24.7)$ & $1(1.4)$ & $0(0)$ & $0(0)$ \\
\hline $\begin{array}{l}\text { The Instructor returns the graded scripts etc. in a } \\
\text { reasonable amount of time }\end{array}$ & $47(64.4)$ & $24(32.9)$ & $2(2.7)$ & $0(0)$ & $0(0)$ \\
\hline $\begin{array}{l}\text { The Instructor was available during the specified office } \\
\text { hours and for after class consultations }\end{array}$ & $55(75.3)$ & $17(23.3)$ & $1(1.4)$ & $0(0)$ & $0(0)$ \\
\hline $\begin{array}{l}\text { The Subject matter presented in the course has increased } \\
\text { your knowledge of the subject }\end{array}$ & $46(63.0)$ & $26(35.6)$ & $1(1.4)$ & $0(0)$ & $0(0)$ \\
\hline $\begin{array}{l}\text { The course integrates theoretical course concepts with } \\
\text { real-world applications: }\end{array}$ & $37(50.7)$ & $34(46.6)$ & $2(2.7)$ & $0(0)$ & $0(0)$ \\
\hline $\begin{array}{l}\text { The assignments and exams covered the materials } \\
\text { presented in the course }\end{array}$ & $43(58.9)$ & $43(58.9)$ & $2(2.7)$ & $0(0)$ & $0(0)$ \\
\hline The course material is modern and updated & 36 (49.3) & $37(50.7)$ & $0(0)$ & $0(0)$ & $0(0)$ \\
\hline
\end{tabular}

The following Table-I shows the questions along with data comprising of opinions or responses given by students in terms of $\%$ of agreement.

The study was conducted after approval from the ethical committee of Mohtarma Benazeer Bhutto shaheed medical college. Students in the study participated voluntary.

\section{RESULTS}

lasted for about two and a half months, starting analysed using Statistical Package for Social sciences (SPSS) 21 software. ${ }^{20}$

\begin{tabular}{|c|c|c|c|c|}
\hline $\begin{array}{c}\text { trongly } \\
\text { agree }\end{array}$ & $\begin{array}{c}\text { Agree } \\
\mathbf{n}(\%)\end{array}$ & $\begin{array}{c}\text { Uncertain } \\
\mathbf{n}(\%)\end{array}$ & $\begin{array}{c}\text { Disagree } \\
\mathbf{n}(\%)\end{array}$ & $\begin{array}{c}\text { Strongly } \\
\text { disagree }\end{array}$ \\
\hline $\mathbf{n}(\%)$ & & &
\end{tabular}

$49(67.1)$

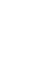


From the results it has been concluded that most of the students of MBBSMC, Mirpur AJK, enrolled in the fourth year of their study agree that overall, the performance of instructor during the newly adapted COVID-19 resultant online education approach was satisfactory. Out of the total 73 students who took part in the survey, 57 (78.1\%) students strongly agree and $16(21.9 \%)$ agreed that their appointed instructors were well prepared for each online lecture and demonstrated the required knowledge of the subject that was being taught online. 29 (39.7\%) students agreed that their instructors completed the whole coursework. $49(67.1 \%)$ students also seem to be strongly agreed, while $22(30.1 \%)$ agreed upon additional material apart from the textbook being provided to them by the instructor to compensate for the lack of in person interaction during lecture. $54(74.0 \%)$ students strongly agreed and 19 $(26.0 \%)$ agreed that their appointed instructor communicates the subject very effectively through online means while also encouraged the students for class participation. Further agreement on effectiveness of online education is confirmed by majority student agreeing on the fact that the subject matter presented in the lecture has resulted into enhancement of their knowledge of the subject being taught. Majority of students i.e. $56(76.7 \%)$ and $52(71.2)$ strongly agreed while $16(21.9 \%)$ and $20(27.4 \%)$ agreed on aspects of performance of instructors such as prompt arrival and departure of the Instructor and that the Instructor was available for after class discussion or consultations. $54(74.0 \%)$ strongly agreed while $18(24.7 \%)$ agreed that online examinations were marked fairly and they were handed over the transcripts and results in usual or reasonable time duration by the instructor.

Students seem divided over the magnitude of their agreement, on the overall conductive environment of the online classes. Results showed that $38(52.1 \%)$ students strongly agreed, while $27(37.0 \%)$ students just agreed and $8(11.0 \%)$ were uncertain whereas $56(76.7 \%)$ participating students strongly agree 17 (23.3\%) participants agree that the overall conductive environment for learning was maintained. Students also seem divided over the magnitude of agreement over application of concepts being taught to them theoretical in the online classes. $37(50.7 \%)$ students strongly agreed while 34 (46.6\%) students just agreed on the integration of the course's theoretical concepts with realworld applications or implementation and 2 $(2.7 \%)$ students were uncertain about it. Also, the agreement seemed divided on the subject of assignments being given to students along with the examinations being relevant to the material presented in the course during online education. Results showed that $43(58.9 \%)$ students strongly agreed while 43 (58.9\%) just agreed about assignments and examinations being relevant to what was being taught to them. 36 (49.3\%) students strongly agreed and $37(50.7 \%)$ agreed on the course material being modern and maintained updated.

\section{DISCUSSION}

This study addresses the effectiveness of online education from the perspective of the students of MBBSMC AJK from the $4^{\text {th }}$ year MBBS program. The survey conducted carried 17 questions that addressed three major aspects or areas. First was the efficiency of online education and its dependence upon how quickly instructors adapted the newly developed protocols for the online education. Hence, most of the survey questions were designed to focus on the preparedness and performance of the Instructor for online lectures during COVID-19 crisis. Survey asked direct questions about the subject or topic knowledge of the instructor and whether the online education model resulted in full completion of the course. Some questions raised the issues of instructor's additional help after class to assist the students understand the lecture for after class consultation. This help can come from additional material apart from the textbook provided by the instructor to the student.

Second set of questions was related to the maintenance of an environment that is best for learning. These details include overall attitude of instructor towards online education, his or her arrival and departure on time, efficiency in grading, promptness in returns the transcripts etc. This set of questions addresses the administrative 
efficiency of the online education which is more of a responsibility of the administration of the higher education. It does involve instructors as well but is mostly the job of the administration. It shows the overall performance of the education institution in adaptation of the online education model.

In the third set of questions, students were directly asked about the effectiveness of the subject matter presented in the course and whether the assignments and examinations actually covered the materials presented in the course. They were also asked to address how modern their course is. Hence, this study evaluated whether the online teaching for medical students was an effective alternate during COVID-19 crisis. By the results obtained from the study, students seem overall satisfied with online classes. As other researches are reported for other medical universities of Pakistan, the student of MBBSMC AJK from the $4^{\text {th }}$ year MBBS program were also strongly satisfied with the performance of the instructor, content of their offered courses as well as environment of online classes. The only area which was less satisfying than others was method of examination and assignment and upgradation of their courses. Because of lack of digital resources in the country itself, the examination, assignment submission tools are not in excess of students from lesser developed rural areas. Hence, this aspect can be made better by planning a rather more robust method of development of tools for submission of assignments or taking examinations more efficiently. Probably, universities will need to be provided with a national examination grid of some sort by Higher Education Commission (HEC) that will be easy to access and works proficiently. Similarly, another aspect that needs improvement is the upgradation of the coursework which can be improved by implementation of such a policy that will make the modernisation of coursework and instructors knowledge mandatory. This requirement exists not only for online education but also traditional in person lectures.

Comparative to other similar studies conducted before, small sample size and narrow selection criteria are the two major limitations of this research study. ${ }^{3,9,15}$ The small sample size limits the ability of this research study to reveal anything beyond the perspective of specific group of students in one higher education institute i.e. $4^{\text {th }}$ year students of MBBSMC. Future researches of similar nature should either increase the sample size or use more broader selection techniques to cover for more diversity within the sample. Also, as the results are only based on students' perspective, the inclusion of faculty opinions in future studies might help in understating the broader issues faced by instructors regarding online education. The conclusions of this research study are based on the opinions of students of MBBSMC only, hence, analysing the opinions of other universities might produce more accurate results as location of institutions and location wise background of their students may generate more reliable information.

\section{CONCLUSION}

Study concluded that the students of the MBBSMC Mirpur AJK were satisfied with the performance of the appointed instructors for the online education during COVID-19. Such strong agreement seems to be missing in the effectiveness of examinations and assignments during online education and modernisation of the coursework. Hence, these areas need to be focussed on. Such research can be made even better with increase in sample size and including more broader opinions from other stakeholders and other institutions.

\section{Copyright $@ 20$ Nov, 2020.}

\section{REFERENCES}

1. Cucinotta D, Vanelli M. WHO declares COVID-19 a pandemic. Acta Bio Medica Atenei Parmensis. 2020; 91(1):157-60. https://doi.org/10.23750/abm.v91i1.9397

2. Saqlain M, Munir MM, Ahmed A, Tahir AH, Kamran $\mathrm{S}$. Is Pakistan prepared to tackle the coronavirus epidemic? Drugs Ther Perspect. 2020; 20:1-2. https:// dx.doi.org/10.1007\%2Fs40267-020-00721-1

3. Adnan M, Anwar K. Online Learning amid the COVID-19 Pandemic: Students' Perspectives. Journal of Pedagogical Sociology and Psychology. 2020; 2(1):45-51. https://eric.ed.gov/?id=ED606496 
4. Ali N. Students disappointed with online teaching system amid COVID-19. Retrieved from Daily Times: https://dailytimes.com.pk/587446/studentsdisappointed-with-online-teaching-system-amidcovid-19. 2020. https://doi.org/10.29333/ejmste/8240

5. Toquero CM. Challenges and opportunities for higher education amid the COVID-19 pandemic: The Philippine context. Pedagogical Res. 2020; 5(4):em0063. https://doi.org/10.29333/pr/7947

6. Crawford J, Butler-Henderson K, Rudolph J, Malkawi B, Glowatz M, Burton R, Magni P, Lam S. COVID-19: 20 countries' higher education intra-period digital pedagogy responses. J Appl Learn Teach. 2020; 3(1):1-20. https://doi.org/10.37074/jalt.2020.3.1.7

7. Basilaia G, Kvavadze D. Transition to online education in schools during a SARS-CoV-2 coronavirus (COVID-19) pandemic in Georgia. Pedagogical Res. 2020; 5(4):1-9. https://doi.org/10.29333/pr/7937

8. Mukhtar K, Javed K, Arooj M, Sethi A. Advantages, Limitations and Recommendations for online learning during COVID-19 pandemic era. PaK J Med Sci. 2020; 36(COVID19-S4):27-31. https://dx.doi. org/10.12669\%2Fpjms.36.COVID19-S4.2785

9. Farid S, Ahmad R, Niaz IA, Arif M, Shamshirband S, Khattak MD. Identification and prioritization of critical issues for the promotion of e-learning in Pakistan. Comput. 2015; 1(51):161-171. https://doi.org/10.1016/j. chb.2015.04.037

10. Al-Samarraie $\mathrm{H}$, Teng BK, Alzahrani Al, Alalwan $\mathrm{N}$. E-learning continuance satisfaction in higher education: A unified perspective from instructors and students. Stud. High. Educ. 2018; 43(11):20032019. https:// doi.10.1080/03075079.2017.1298088.

11. Chen L, NathR, Tang Z.Understanding the determinants of digital distraction: An automatic thinking behaviour perspective. Comput. 2020;1(104):106195. https://doi. org/10.1016/j.chb.2019.106195

12. Kwary DA, Fauzie S. Students' achievement and opinions on the implementation of e-learning for phonetics and phonology lectures at Airlangga University. Educação e Pesquisa. 2018; 44. https://doi. org/10.1590/s1678-4634201710173240
13. Cassum S, Mansoor K, Hirji A, David A, Aijaz A. Challenges in Teaching Palliative Care Module Virtually during COVID-19 Era. Asia Pac J Oncol Nurs. 2020; 7(4):301-304. https://doi 10.4103/apjon. apjon_42_20

14. Kizilcec RF, Pérez-Sanagustín M, Maldonado JJ. Self-regulated learning strategies predict learner behaviour and goal attainment in Massive Open Online Courses. Comput Educ. 2017; 104:18-33. https://doi.org/10.1016/j.compedu.2016.10.001

15. Farooq F, Rathore FA, Mansoor SN. Challenges of Online Medical Education in Pakistan During COVID-19 Pandemic. J Coll Physicians Surg Pak. 2020; 30(Supp1):S67-S69 https://doi.org/10.29271/ jcpsp.2020.Supp1.S67.

16. Liguori E, Winkler C. From Offline to Online: Challenges and Opportunities for Entrepreneurship Education Following the COVID-19 Pandemic. Entrepreneurship Education and Pedagogy. 2020; 3(4):346-51. https:// doi.org/10.1177\%2F2515127420916738

17. Broadbent J, Poon WL. Self-regulated learning strategies \& academic achievement in online higher education learning environments: A systematic review. The Internet and Higher Education. 2015; 1(27):1-3. https://doi.org/10.1016/j.iheduc.2015.04.007

18. Hodges C, Moore S, Lockee B, Trust T, Bond A. The difference between emergency remote teaching and online learning. Educause Review. 2020. https:// er.educause.edu/articles/2020/3/the-differencebetween-emergency-remote-teaching-and-onlinelearning.

19. Rashid AA, Rashid MR, Yaman MN, Mohamad I. Teaching Medicine Online During the COVID-19 Pandemic: A Malaysian Perspective. Bangladesh J Med Sci. 2020; 20:77-81. https://doi.org/10.3329/bjms. v19i0.48170

20. Priyanka G. Application of SPSS programme in the field of social science research. Int. J. Recent Technol. 2020; 8(5):2424-2427. https://doi.org/10.35940/ijrte. d9260.018520 


\begin{tabular}{|c|c|c|c|}
\hline \multicolumn{4}{|c|}{ AUTHORSHIP AND CONTRIBUTION DECLARATION } \\
\hline Sr. \# & Author(s) Full Name & Contribution to the paper & Author(s) Signature \\
\hline 1 & Faisal Bashir & Direct/Evaluation. & \\
\hline 2 & Amna Ahmad Noor & Direct/Evaluation. & \\
\hline 3 & Ejaz Ahmad & Indirect / evaluation. & 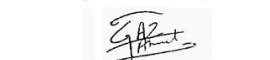 \\
\hline 4 & Zafryab Ali & Indirect / evaluation. & ghis \\
\hline 5 & Syed Manzoor Iqbal & Indirect / evaluation. & Wés \\
\hline 6 & M. Kaleem & Indirect / evaluation. & $i_{y}^{\prime}=$ \\
\hline
\end{tabular}

